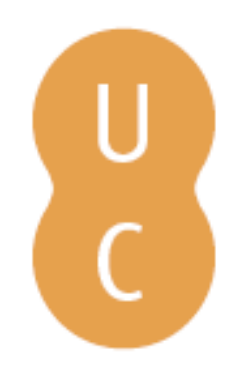

\title{
nommalina
}

\section{Hoshin kanri: a strategic approach to maintenance performance management}

Autor(es): $\quad$ Chemweno, Peter; Pintelon, Liliane; Muchiri, Peter

Imprensa da Universidade de Coimbra; Faculdade de Ciências e

Publicado por: Tecnologia da Universidade de Coimbra, Departamento de Engenharia Mecânica

URL persistente:

URI:http://hdl.handle.net/10316.2/33337

DOI:

DOI:http://dx.doi.org/10.14195/978-972-8954-42-0_22

Accessed : $\quad$ 26-Apr-2023 15:46:34

A navegação consulta e descarregamento dos títulos inseridos nas Bibliotecas Digitais UC Digitalis, UC Pombalina e UC Impactum, pressupõem a aceitação plena e sem reservas dos Termos e Condições de Uso destas Bibliotecas Digitais, disponíveis em https://digitalis.uc.pt/pt-pt/termos.

Conforme exposto nos referidos Termos e Condições de Uso, o descarregamento de títulos de acesso restrito requer uma licença válida de autorização devendo o utilizador aceder ao(s) documento(s) a partir de um endereço de IP da instituição detentora da supramencionada licença.

Ao utilizador é apenas permitido o descarregamento para uso pessoal, pelo que o emprego do(s) título(s) descarregado(s) para outro fim, designadamente comercial, carece de autorização do respetivo autor ou editor da obra.

Na medida em que todas as obras da UC Digitalis se encontram protegidas pelo Código do Direito de Autor e Direitos Conexos e demais legislação aplicável, toda a cópia, parcial ou total, deste documento, nos casos em que é legalmente admitida, deverá conter ou fazer-se acompanhar por este aviso.

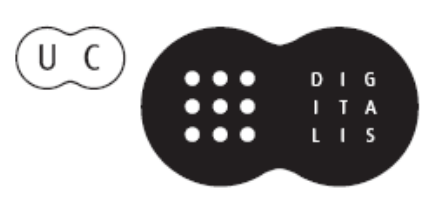




\title{
Hoshin kanri: a strategic approach to maintenance performance management
}

\author{
Peter Chemweno ${ }^{1}$, Liliane Pintelon ${ }^{1}$; Peter Muchiri $^{2}$ \\ ${ }^{1}$ peterkipruto.chemweno@kuleuven.be; ${ }^{1}$ liliane.pintelon@kuleuven.be; ${ }^{2}$ peter.muchiri@dkut.ac.ke \\ ${ }^{1}$ Centre for Industrial Management, KU Leuven, \\ Heverlee, Belgium \\ ${ }^{2}$ Dedan Kimathi University of Technology, \\ Nyeri, Kenya
}

\begin{abstract}
The Hoshin kanri is a popular methodology for strategic policy planning and deployment. The approach is widely used by firms as a tool for aligning organizational objectives at the strategic level with key performance measures at the tactical and operational levels. Moreover, the methodology presents a structured means for translating performance measures into specific performance indicators. Based on the performance indicators, decision makers are able to measure the performance of processes/systems and consequently, implement corrective actions. However, despite its successful implementation in diverse sectors such as finance, banking and quality management, not much work is mentioned regarding its use in maintenance performance management. Yet, recent literature underscores the strategic importance of performance measurement as a means of evaluating the effectiveness of implemented maintenance strategies. This paper adapts the Hoshin kanri technique for strategic maintenance performance management. The tool's applicability is demonstrated through the case study of an edible oil processing facility. The technique proposes a structure for; aligning strategic objectives to key performance indicators at the shop floor, setting performance targets and implementing improvement actions. Moreover, the technique is user intuitive and involves personnel at all levels in the organization.
\end{abstract}

Keywords-Hoshin kanri, policy deployment, asset maintenance.

\section{INTRODUCTION}

In recent years, research on asset maintenance has gained considerable attention. Indeed, for operable assets, the operation and maintenance costs often constitute as much as $70 \%$ of the total ownership cost [1]. For this reason, the maintenance function is no longer viewed as a 'necessary evil', but of strategic importance to the organizations' competitiveness. Often, the role of the maintenance function is to initiate and implement maintenance strategies that mitigate asset failures. Well-known maintenance strategies include; the Failure Based Maintenance (FBM), Time/Use Based Maintenance (UBM/TBM) and Condition Based Maintenance (CBM) [2]. Linked to these strategies are a set of maintenance interventions, e.g. corrective maintenance actions, in the event of failure, or preventive maintenance actions, prior to component failure.
However, evaluating the effectiveness of implemented strategies is often not straightforward. This informs the recent proliferation of literature on maintenance performance measurement [3]. According to Neely [4], performance measurement is the process of quantifying a purposeful action, where the process of quantification is measurement and the purposeful action equates to performance. Achieving a purposeful action requires a structured approach. One common approach is designing a maintenance performance reporting system. Ideally, the reporting system consists of defined set of maintenance performance indicators that assist practitioners evaluate the performance of past maintenance. Examples of such activities include evaluating the effectiveness of maintenance interventions undertaken or quality of repair actions. In this paper, the performance indicator is defined as $a$ variable that expresses quantitatively the effectiveness, efficiency or productivity of a system against a given norm or target [2].

Ideally, the maintenance performance indicators ought to cascade from the strategic goals/objectives defined by top management. This requires a methodological approach. However, this is often not the case in many organizations where generic list of indicators is often adopted [5]. In addition, performance indicators are derived from established standards, e.g. the EN 15341. As such, existing maintenance performance reporting models seldom link performance indicators to the strategic goals/objectives. Moreover, several limitations are noted with existing reporting models which include lack of structured approach for performance target setting, ad-hoc formulation of corrective actions and absence of systematic improvement actions, e.g. as proposed through the quality improvement cycle.

This article attempts to address the above concern by proposing the Hoshin kanri (H-K) methodology for policy deployment, performance measurement and implementing improvement actions. The remainder of this paper is organized as follows. In Section 2, introductory concepts in maintenance performance reporting is discussed. This is followed by a brief review of existing performance reporting models. The review highlights gaps in existing models. In Section 3, phases in the Hoshin kanri methodology are discussed. Section 4 describes adaptation of the Hoshin kanri for maintenance performance management where the methodology is demonstrated through the case study for edible oil - solvent extraction facility. 
Section 5 draws important conclusions and directions for future work.

\section{MAINTENANCE PERFORMANCE REPORTING}

\section{A. Overview on performance reporting}

Performance reporting is an integral aspect in asset management and by extension, maintenance decision making. Ideally, performance reporting strives towards excellence in maintenance and defines several aspects which include; defining a mission statement, setting goal and objectives, strategy development, performance measurement and finally, formulation of corrective actions [2].

In many organizations, the maintenance function is the responsibility of the maintenance department whose core task is formulating maintenance programs. Often, the programs detail the type of strategy, maintenance intervention or repair actions. As mentioned in the previous section, performance reporting provides an important structure for evaluating the effectiveness of the implemented programs. This is reflected by the maintenance performance indicators. In practice, maintenance performance measurement is characterized by diverse set of metrics and indicators e.g. see Kumar, Galar [3].

However, selecting appropriate indicators for the organization is often not straightforward. As a result, several authors propose multi-criteria decision making models (MCDM). For instance, Parida [6] propose a multi-criteria hierarchical framework for maintenance performance measurement. The framework proposes several performance indicators cascaded to the different organizational levels, i.e. strategic, tactical and operational levels. An analytic network process approach (ANP) is adopted by Van Horenbeek and Pintelon [7] where the maintenance performance indicators are prioritized and cascaded to all organizational levels. Recently, Gonçalves, Dias [8] propose a methodology for selecting key performance indicators for maintenance through the ELECTRE, a multi-criteria decision making approach.

The models discussed above propose an important structure that potentially guides practitioners towards selecting the right indicators. However, the models seldom address performance measurement aspects, e.g. performance target setting, performance measurement, and formulating maintenance improvement actions. These gaps are partially addressed by performance reporting models discussed in the next section.

\section{B. Performance reporting models}

Performance reporting models provide an important measurement tool that incorporates performance measurement aspects. The models aid in structuring performance measurement with a view of addressing the following concerns [2]:

- What is required for carrying out maintenance (input)?

- What is expected from the maintenance interventions (output)?
- What and how much maintenance is required (process)?

- What is being done to improve maintenance processes (continuous improvement)?

In literature, performance reporting models are discussed. Several of the models are based on the well-known balanced score card (BSC) [9]. Notable examples include Tsang [10] where the BSC approach is adopted for maintenance performance management. In the study, the corporate strategy is first translated to maintenance strategy, followed by maintenance objectives, and finally action plans. Moreover, the action plans are linked to performance measurement where periodic review against targets is implemented.

In other studies, Alsyouf [11] demonstrate how the BSC can be used by the organization to improve the return on investment (ROI) through adopting condition based maintenance strategy. Here, the overall equipment effectiveness (OEE) and cost measures are adapted as the key indicators of maintenance effectiveness. More recently, Galar, Parida [12] propose an approach based on the BSC where the maintenance performance indicators are derived from four BSC's perspectives, i.e. financial, customer satisfaction, internal processes and learning/growth. In the study, the authors demonstrate how the indicators are deployed to all levels in the organization. Using a different approach, Kutucuoglu, Hamali [13] propose a framework for maintenance performance management based on the quality function deployment (QFD) technique. In the study, the maintenance metrics/indicators are aligned to organizational goals via the QFD matrix.

The models described above form an important basis for developing performance reporting systems. Nevertheless, several important aspects that are central to performance reporting are insufficiently addressed. These include setting performance targets and formulating maintenance improvement actions.

\section{HOSHIN KANRI}

\section{A. Overview of the hoshin kanri}

The Hoshin kanri is a Japanese management term that loosely translates to policy deployment. The methodology traces its origin to early work in total quality control pioneered by the Japanese manufacturing industry. The methodology embraces four important steps $[14,15]$ :

1. Establish the organizational vision followed by translating the vision into goals, aims, and future scope;

2. Formulating strategy, objectives, key performance indicators (KPI's), performance benchmarks and targets;

3. Deploying the objectives, KPI's, benchmarks and targets to all levels in the organization; 
4. Performance evaluation, control and implementing continuous improvement actions with the aid of the Plan-Do-Check-Act (PDCA) cycle.

The Hoshin kanri forms an important pillar for Total Quality Management (TQM) by presenting a comprehensive methodology for quality management. This contrasts to standard practice where TQM is implemented using individual quality management tools, e.g. six-sigma or statistical process control [16]. As a result, the Hoshin kanri integrates core management aspects into one framework, right from strategic planning to control. Through the integration, decision makers are able to formulate long-term plans, translate the plans into short-term objectives, derive KPI's, set performance targets, and deploy the KPI's, benchmarks and targets. Moreover, the Hoshin kanri allows one to formulate and implement improvement actions in a structured way. Figure 1 depicts important elements of the Hoshin kanri.

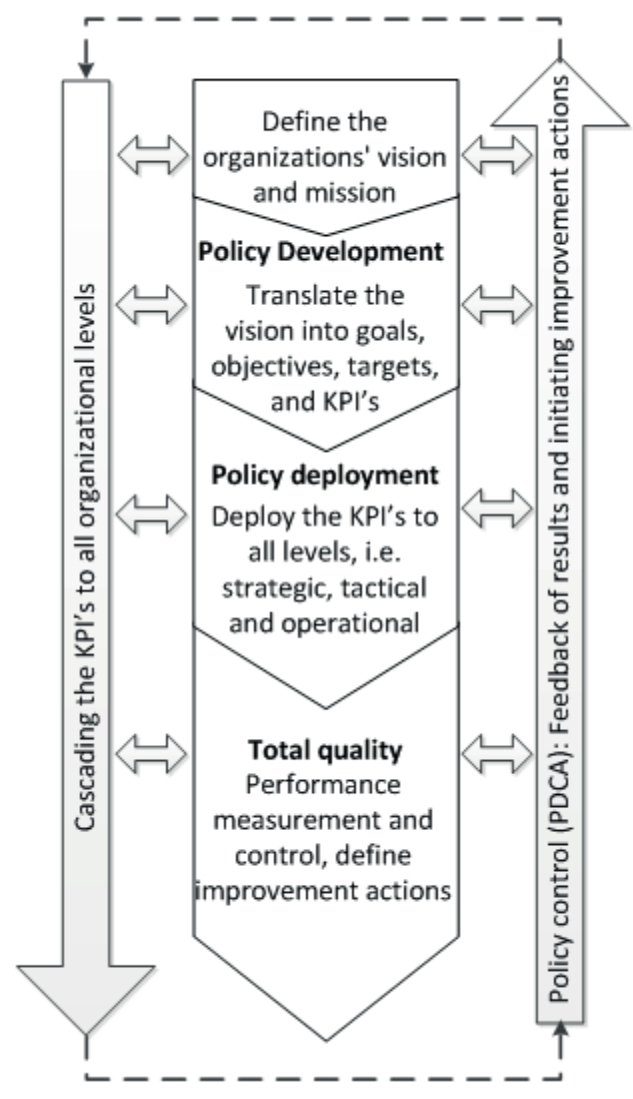

Fig. 1. Elements of the Hoshin kanri planning [16].

An important feature of the Hoshin kanri is the PDCA cycle for ensuring policy control. The cycle allows decision makers to measure the performance of the system against set targets. This is achieved through periodic review of the KPI's. Based on the performance, policy control activities are initiated. These may include implementing improvement actions, e.g. optimizing maintenance schedules for critical failure modes or improving spare parts order lead time through better inventory management. Such actions constitute the 'plan' and 'do' phase. Of course, to ensure that the implemented measures are achieving the desired results, the 'check' phase is undertaken through comparing the actual performance against desired targets. For out of spec measures, corrective actions become necessary. Here, the 'act' phase becomes rather important.

The cyclic PDCA approach is continuously repeated thus leading to improved management process. Indeed, the Hoshin kanri is a rather valuable tool in that it aligns employees at all levels of the organization to the organizational vision [16].

\section{B. Industrial application of Hoshin kanri}

One of the earliest industrial applications of the Hoshin kanri for quality control was the Bridgestone tire company in Japan [17]. Since then, its use in diverse industries, e.g. semiconductor manufacturing, automobile assembly and general engineering firms is reported [18-20]. In the aforementioned organizations, the Hoshin kanri is largely applied in quality improvement, productivity improvement and strategic policy deployment.

However, despite its wide application, not much work is reported regarding its use in maintenance performance management. Yet, performance measurement performs a critical role in maintenance decision making. This informs the reason for this article. In the following sections, the methodology for Hoshin kanri as adapted in this article is discussed. This is followed by a demonstration of its use in a case study.

\section{CASE STUDY}

\section{A. Case background}

This section discusses application of the Hoshin kanri methodology for performance management. The company considered in this study operates an edible oil processing facility. The production process entails extracting oil from oilseed through a solvent extraction process. The solvent used in this case is hexane. The extract, i.e. solvent-oil mixture, is directed to condenser units where the solute is separated from the solvent through an evaporation and condensation process. Afterwards, the extracted oil is channeled to a refining section, while the recovered solvent is re-circulated to the solvent chamber to facilitate further oil extraction.

The solvent extraction process is a controlled chemical process and requires the correct conditions for optimal extraction. Moreover, the solvent has low boiling point and highly flammable. This leads to important maintenance challenges should the extractor breakdown. Often, when a failure occurs, the extractor is stopped and allowed to cool down, until hexane fumes liquefy, a process that takes several hours. Moreover, both the extract and feed stock have to be flashed out of the system, leading to production and quality losses. In addition to production losses, any maintenance activity leading to sparking is avoided, e.g. striking one metal surface against another (hammering or arc welding). This is primarily due to the flammable nature of hexane. 
For the facility, periodic maintenance is undertaken. However, considering the rising demand for the company's products, the maintenance function is often constrained in terms of opportunity for carrying out maintenance. Moreover, in absence of a robust performance measurement tool, tracking the effectiveness of maintenance interventions is not straightforward. For these reasons, implementing performance management was considered necessary.

\section{B. Case methodology}

This section presents the proposed methodology for the Hoshin kanri planning applied in the context of the case study. Figure 2 depicts the methodological steps, where the cyclic relationships between the different steps are linked via the PDCA cycle. The steps are as follows:

1) Establish the organization vision and mission;

2) Translate the vision into both short term and longterm objectives;

3) For each objective, define key performance indicators (KPI's);

4) Establish the performance targets for each KPI's;

5) Deploy the KPI's to all organizational levels;

6) Formulate a structure for data collection relevant to the KPI's, e.g. failure data for computing reliability;

7) Depending on the KPI's, conduct periodic performance measurement. The review period may be short-term, e.g. daily/weekly/monthly or longterm, e.g. quarterly/yearly.

8) For out-of-spec KPI's, formulate corrective and improvement actions that enhance the effectiveness of implemented activities.

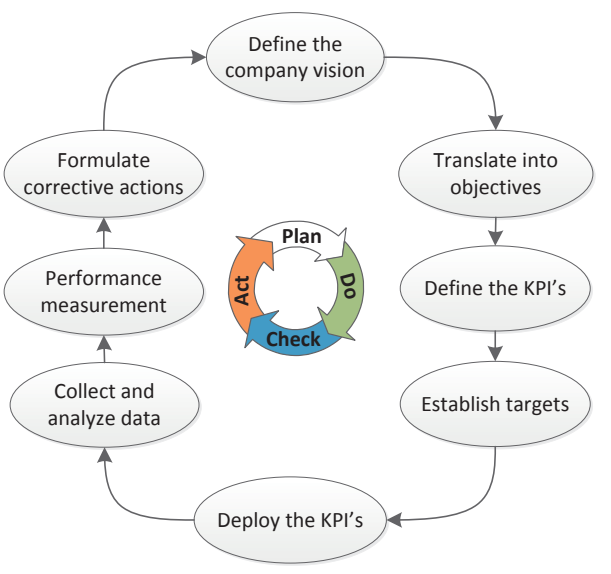

Fig.2. Methodology for implementing Hoshin kanri planning

(1) Establishing the vision of the organization

In this step, the top management defines a vision espousing the ideals of the company. The vision is often defined through the company mission statement. In addition to the company mission, each function within the organization translates the mission into specific statement(s) relevant to the unit. For the maintenance function, the specific statement is:

"Enhancing safety, quality and productivity"

The statement enumerates aspects the maintenance function considers as most important. Moreover, the three aspects are inter-linked to maintenance in that a faulty component within the solvent extraction plant may trigger maintenance actions. Depending on the failure mode, the repair action may expose the technician to explosion (safety) hazard, i.e. through hexane fumes. Moreover, the failure mode may result in plant shutdown thus adversely affecting the production throughput (productivity) and/or product quality, e.g. by having to remove the feed stock and extract.

\section{(2) Translating vision into maintenance objectives and performance indicators}

In this step, the vision is translated into maintenance objectives which specify how the goals/vision will be achieved. Table 1 depicts translation of the goal "maximize productivity through effective equipment utilization". Here, the goal is translated to five main objectives and further cascaded to several KPI's (see column 3).

The objectives described in column 2 represent recurrent maintenance problems as perceived by the maintenance engineers and technicians in the organization. Moreover, the objectives were arrived at through a rigorous brain storming session. Here, the Ishikawa approach is adopted as a tool for organizing ideas and suggestions elicited during the brain storming sessions.

TABLE I. TRANSLATING VISION INTO OBJECTIVES AND KPI'S

\begin{tabular}{|c|c|l|c|}
\hline Vision & & \multicolumn{1}{|c|}{ Maintenance objectives } & KPI's \\
\hline \multirow{2}{*}{$\begin{array}{c}\text { Maximize } \\
\text { productivity } \\
\text { through effective } \\
\text { equipment } \\
\text { maintenance }\end{array}$} & 1 & $\begin{array}{l}\text { Reduce hexane leaks through } \\
\text { periodic inspection of mechanical } \\
\text { seals and pipeline flanges }\end{array}$ & $\begin{array}{c}\text { Hexane loss } \\
\text { (kg/ton } \\
\text { throughput) }\end{array}$ \\
\cline { 2 - 5 } & 2 & $\begin{array}{l}\text { Reduce repair time through } \\
\text { effective maintenance planning } \\
\text { Adopt more time based } \\
\text { maintenance as compared to } \\
\text { failure based maintenance }\end{array}$ & $\begin{array}{c}\text { Mean time to } \\
\text { repair } \\
\text { (MTTR) }\end{array}$ \\
\cline { 2 - 5 } & 4 & $\begin{array}{c}\text { Percentage } \\
\text { scheduled } \\
\text { repair/ Total } \\
\text { repairs }\end{array}$ \\
\cline { 2 - 5 } & Redfective operational planning & $\begin{array}{c}\text { Percentage } \\
\text { response time } \\
\text { to initiate } \\
\text { shutdown }\end{array}$ \\
\hline
\end{tabular}

Once the critical maintenance objectives were agreed on, the next step was assigning appropriate KPI's to each

\footnotetext{
${ }^{1}$ Adapted from Muchiri and Pintelon [5]
} 
objective. It is important to mention that each objective may be represented by several alternative KPI's. However, in this article, the main criterion for selecting the KPI's was user intuitiveness. For instance, the maintenance objective "improve repair quality" may be represented by several quantitative KPI's, e.g. imperfect repair models [21]. However, such models may not be easily understood by maintenance practitioners. As such, a more meaningful indicator is "percentage of repair requiring rework"[5].

In total, the mission statement for the maintenance function is translated to a total of 26 maintenance objectives. It is worth mentioning that several of the aforementioned objectives are monitored across departments. For instance, the maintenance objective "improve the extractor's OEE" is monitored by the maintenance, production, and quality departments. This is because, the OEE is defined by the product of three metrics; availability (A), performance rate $(\mathrm{P})$ and quality rate $(\mathrm{Q})[22]$. The availability (A) is a maintenance function performance indicator measured by the following equation:

$$
\text { Availability }=\frac{M T B F}{M T B F+M T T R}
$$

Where MTBF is the mean time between failure and MTTR is the mean time to repair.

On the other hand, the quality rate $(\mathrm{Q})$ is viewed as an indicator for the quality department where the proportion of acceptable product is measured as a percentage of total production throughput. Lastly, the performance rate $(\mathrm{P})$ is an indicator of equipment utilization. An alternative way of representing $\mathrm{P}$ is through monitoring the production throughput. As such, the metric P measures the operational effectiveness, and for this reason, an indicator for the production department. For this reason, the metrics are deployed and monitored separately by the aforementioned departments. The OEE is afterwards aggregated.

\section{(3) Setting performance targets}

From literature, several approaches are suggested for setting performance benchmarks and targets. Examples include; target setting by maintenance managers, use of industry-wide benchmarks, and ad-hoc approaches [3]. However, the aforementioned approaches seldom take into account the operational and business context. For instance, setting target in an ad-hoc manner may yield unrealistic target(s), thus defeating the primary objective of performance management. On the other hand, relying on industry-wide benchmarks may lead to unrealistic expectations. This is often the case where the organizations vary in terms of the business context, e.g. petro-chemical facility and hospital equipment maintenance. For this reason, authors, e.g. Meekings [23] propose a systems approach for setting performance targets.

In the system approach, the maintenance function is viewed as a system consisting of: (i) a set of inputs, e.g. maintenance technicians, maintenance interventions; (ii) the maintenance process; (iii) and set of outputs, i.e. system performance. The maintenance process is often influenced by several dynamics that may include the type and age of the equipment, (un)availability of diagnostic equipment, or human factors, e.g. personnel expertise. For this reason, the system performance (i.e. output) is rather stochastic. This complicates the target setting exercise. For such complex processes, statistical process control (SPC) charts has been suggested in diverse fields, e.g. in quality management and process control. These charts vary in complexity and may be univariate or multivariate [24]. Univariate charts track a single process parameter, while multivariate chart tracks multiple process parameters.

The attractiveness of using SPC is that the charts provide a statistical basis for target setting, taking into consideration the process variability. Thus, upper and lower control limits (UCL and LCL) are computed based on performance variables collected from the system. Examples of such variables include the time to failure (TTF) or system availability.

In this article, a univariate SPC, i.e. the $X$ bar $-R$ chart is applied for setting targets for several performance measures. Here, $X_{b a r}$ represents the sample average, while the range (R) represents the system variability. Several out of spec values may indicate an unstable maintenance process, e.g. inappropriate maintenance schedule or low repair quality.

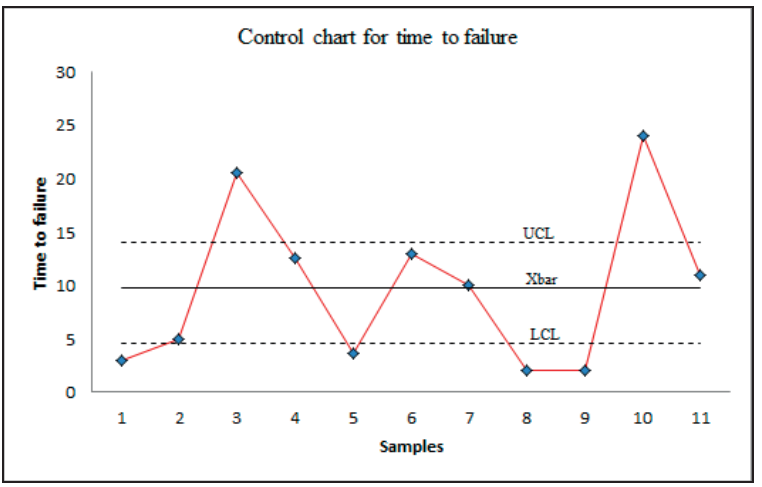

Fig. 3. Statistical control charts for time to failure.

Figure 3 depicts the $\mathrm{X}_{\text {bar }}$ process control for the time to fail of a solvent pump. From the figure, the trend represents eleven data points representing the TTF's for the solvent pump at different time instances. As clearly seen, the TTF varies from data point to data point. Based on the sample TTF's, the UCL and LCL are computed using the equations:

$$
\begin{aligned}
U C L & =\bar{x}+A_{2} R \\
L C L & =\bar{x}-A_{2} R
\end{aligned}
$$

Where the factor $\mathrm{A}_{2}$ depends on the sample size $n$ and read directly from SPC tables. From Figure 3, it is clear that several TTF's are outside the required thresholds, indicative of an unstable maintenance process. As such, one may conclude that there is the need to review the current maintenance interventions and undertake necessary corrective actions. Proposed actions may include shortening the maintenance schedule, e.g. from 4 to 3 months, reviewing the repair interventions, or re-training technicians on best repair practices specific to the type of solvent pump. 


\section{(4) Data collection and performance measurement}

In this phase, data relevant to the performance measurement exercise is collected and analyzed. Often, the data is linked to the KPI's and as such, should be appropriately structured. For instance, computing equipment availability, defined earlier in Equation 1 requires data on two performance metrics; time to failure and time to repair. As such, an appropriate data structure for the aforementioned metrics would include details such as; time the equipment failed, the repair time, and the time of commissioning the equipment after repair. For the case company, the information is captured from work orders generated from a computerized maintenance management system (CMMS).

Once the KPI's are derived, trend analysis, e.g. depicted in Figure 3 is performed with a view of tracking the performance of the individual indicators. However, it should be mentioned that not all KPI's are evaluated through the SPC's. Rather, target setting should be based on the criticality of the particular KPI. For instance, safety related KPI's, e.g. number of accidents should at all times be zero as per legislation. Other KPI's, e.g. operation or quality related may rely on targets established through the SPC charts. Nevertheless, the trend analysis is important given it maps the KPI's evolution with time, and as a result, trigger corrective/improvement actions.

\section{(5) Formulate corrective actions}

In this step, corrective actions are formulated for specific equipment. As previously mentioned, the actions are triggered by out of spec information derived from the trend analysis. To illustrate, consider the trend analysis for the hexane pump depicted in Figure 3. The TTF evolution indicates poor reliability due to several points that are out of spec. An indepth analysis indicates that the failures are linked to solvent leakage through the pump's mechanical seals. Often, the root cause of this problem relates to assembly process for the seals given the precise tolerances required. As a result, observing the installation procedure specified in the assembly manual is critical. Moreover, specialized tolerance gauges are necessary for successful assembly and dis-assembly.

However, following the assembly procedures and using the tolerance gauges requires a specific level of expertise, training and skills. Moreover, interpreting the technical manuals is often not straightforward, and as such influences the quality of the repair process. For the case company, scheduled maintenance is adopted where the seals are replaced every 6 months. For failures that occur in between the schedules, breakdown maintenance is performed. In addition, the repair action seldom follows the documented assembly procedures, but rather, relies on the experience of individual technician(s).

Table 2 describes the proposed improvement actions, Gantt chart planning, and responsibility assignment for implementing the action plans. The structured approach described in Table 2 ensures that the proposed actions are implemented and further, provides a means for follow-up. Moreover, the structure makes it possible to track the effectiveness of proposed actions once implemented. Here, effective action(s) will ideally translate to improved performance, reflected through fewer out of spec point on the SPC charts, or fewer accidents.

TABLE II. FORMULATING CORRECTIVE ACTIONS AND PLANNING

\begin{tabular}{|c|c|c|c|c|c|c|}
\hline & \multirow{2}{*}{ Actions } & \multicolumn{4}{|c|}{ Quarter } & \multirow{2}{*}{ Responsibility } \\
\hline & & 1 & 2 & 3 & 4 & \\
\hline 1 & $\begin{array}{l}\text { Formulate standard installation and repair } \\
\text { procedures }\end{array}$ & $\Rightarrow$ & & & & Maintenance department \\
\hline 2 & $\begin{array}{l}\text { Avail standard installation aids, e.g. finger } \\
\text { gauges, tolerance charts }\end{array}$ & & & & & Management \\
\hline 3 & \begin{tabular}{|l|} 
Re-train technicians on installation \\
procedures and use of installation aids
\end{tabular} & & & & & Original equipment manufacturer \\
\hline 4 & $\begin{array}{l}\text { Standardise the repair procedures and } \\
\text { verify the procedures are followed }\end{array}$ & & & & & Maintenance department \\
\hline
\end{tabular}

To conclude, the different phases of the Hoshin kanri methodology described previously are implemented in MS Excel. The MS Excel worksheet contains modules describing phases of the proposed methodology.

\section{CONCLUSIONS}

In this article, a methodology for maintenance performance management using the Hoshin kanri approach is proposed. The methodology is widely applied in the Japanese manufacturing industries as a tool for strategic policy deployment and total quality control. However, not much work is reported regarding its use in maintenance performance management. This inspite the strategic role of the maintenance function in enhancing the organizations' competitiveness.

In this article, the Hoshin kanri methodology is applied in the case study of an edible oil processor. In the study, we highlight how the organization can translate their vision into maintenance objectives and later, key performance indicators. An attractiveness with the methodology relates to personnel involvement at all levels in the organization, right from the top management to the shop floor where the KPI's are measured. Moreover, by achieving the right KPI's, the vision of the organization is implicitly attained. In conjunction with the Hoshin kanri, statistical process control charts are incorporated with a view of structuring the performance target setting exercise. This is achieved by viewing the maintenance process through the systems approach concept. Linked to the results of the SPC's are corrective and improvement actions and a structured plan that ensures continual improvement is attained systematically.

Future work will evaluate the effectiveness of linking the MS Excel based model to a structured data base, thus allow decision makers to pro-actively monitor the KPI's. Additional future work will look at the possibilities of introducing multivariate SPC's as a means for target setting where there is evidence of close correlation amongst the KPI's.

\section{REFERENCES}

[1] A. Koronios, D. Nastasie, V. Chanana and A. Haider, "Integration through standards-an overview of international standards for engineering asset management," Fourth International Conference on Condition Monitoring, Harrogate, United Kingdom. 2007.

[2] L. Pintelon, and V. Puyvelde, Asset management: the maintenance perspective. Acco, Leuven, 2013.

[3] U. Kumar, et.al., "Maintenance performance metrics: a state-of-the-art review," Journal of Quality in Maintenance Engineering, vol. 19, pp 233-277, 2013. 
4] A. Neely, "The performance measurement revolution: why now and what next?" International Journal of Operations \& Production Management, vol 19(2), pp. 205-228, 1999.

[5] P. Muchiri, L.Pintelon, L.Gelders, H. Martin, "Development of maintenance function performance measurement framework and indicators." International Journal of Production Economics, vol 131(1), pp. 295-302, 2011.

[6] A. Parida, "Development of a Multi-criteria Hierarchical Framework for Maintenance Performance Measurement," Doctoral Thesis. Division of Operation and Maintenance Engineering. Luleå University of Technology, 2006.

[7] A. Van Horenbeek and L. Pintelon, "Development of a maintenance performance measurement framework-using the analytic network process (ANP) for maintenance performance indicator selection." Omega, vol. 42(1), pp. 33-46, 2014.

[8] C. Gonçalves, J. Dias, and V. Cruz-Machado, "Decision Methodology for Maintenance KPI Selection: Based on ELECTRE I," Proceedings of the Eighth International Conference on Management Science and Engineering Management, pp. 1001-1012, Springer Berlin Heidelberg, 2014

[9] R.S. Kaplan, D.P. Norton, and P. Horv6th, "The balanced scorecard." Vol. 6, Harvard Business School Press, Boston, 1996.

[10] A.H. Tsang, "A strategic approach to managing maintenance performance." Journal of Quality in Maintenance Engineering, vol. 4(2), pp. 87-94, 1998

[11] I. Alsyouf, "Measuring maintenance performance using a balanced scorecard approach.” Journal of Quality in Maintenance Engineering, vol. 12(2), pp. 133-149, 2006.

[12] D. Galar, et al., "Maintenance metrics: a hierarchical model of balanced scorecard." IEEE International Conference on Quality and Reliability, 2011

[13] K. Kutucuoglu, et al., "A framework for managing maintenance using performance measurement systems." International Journal of Operations \& Production Management, vol. 21, pp. 173-195, 2001
[14] D. Hutchins, "Hoshin Kanri: The Strategic Approach to Continuous Improvement." Gower, 2012.

[15] Y. Akao, "Hoshin Kanri: Policy Deployment for Successful" Total Quality Management, Taylor \& Francis, 2004.

[16] C. Tennant, and P. Roberts, "Hoshin kanri: a tool for strategic policy deployment." Knowledge and Process Management, vol.8(4), pp.262269.

[17] M. Miyaji, "On promoting the Deming plan". Hinshitsu Kanri, vol. 20, pp. 21, 1969.

[18] C.G. Johannsen, "Strategic issues in quality management: I. Theoretical considerations." Journal of information science, vol. 22(3), pp. 155-164, 1996.

[19] B.J. Witcher, and R. Butterworth, "Hoshin Kanri: Policy Management In Japanese-Owned UK Subsidiaries." Journal of Management Studies, vol. 38(5), pp. 651-674, 2001.

[20] T. Yang, and C. Su, "Application of hoshin kanri for productivity improvement in a semiconductor manufacturing company." Journal of Manufacturing Technology Management, vol. 18(6), pp 761-775, 2007.

[21] P.N. Muchiri, et al., "Modelling maintenance effects on manufacturing equipment performance: results from simulation analysis." International Journal of Production Research, (ahead-of-print): pp. 1-16, 2013.

[22] P. Muchiri, and L. Pintelon, "Performance measurement using overall equipment effectiveness (OEE): literature review and practical application discussion." International Journal of Production Research, vol. 46(13), pp. 3517-3535. 2008.

[23] A. Meekings, "Unlocking the potential of performance measurement: A practical implementation guide." Public Money \& Management, vol. 15(4), pp. 5-12. 1995

[24] S. Bersimis, S. Psarakis, and J. Panaretos, "Multivariate statistical process control charts: an overview." Quality and Reliability Engineering International, vol. 23(5), pp. 517-543. 2007. 